\title{
Pengukuran Kesesuaian Kawasan Transit Blok M, Jakarta Terhadap Kriteria Konsep TOD (Transit Oriented Development)
}

\author{
Muhammad Afif Arsyad dan Ketut Dewi Martha Erli Handayeni \\ Perencanaan Wilayah dan Kota, Fakultas Teknik Sipil dan Perencanaan \\ Institut Teknologi Sepuluh Nopember (ITS) \\ e-mail: erli.martha@urplan.its.ac.id
}

\begin{abstract}
Abstrak - Terletak diantara central business district Kota Jakarta, Blok M yang merupakan salah satu kawasan strategis memiliki potensi dikembangkan berdasarkan prinsip dari Transit Oriented Development (TOD). Hal ini juga didukung dari dokumen perencanaan yang menyatakan bahwa kawasan Blok M, Jakarta merupakan kawasan yang direncanakan dan dikembangkan berdasarkan standar TOD. Konsep TOD merupakan suatu pendekatan rekayasa ruang yang terfokus pengembangannya di sekitar titik transit. Ruang yang dikembangkan nantinya memiliki ciri yakni densitas yang tinggi, diversitas yang beragam serta desain kawasan yang ramah terhadap pejalan kaki. Penelitian ini menggunakan analisis spatial query dan perhitungan rata-rata untuk mengukur tingkat kesesuaian kawasan transit Blok $M$ terhadap kriteria TOD. Berdasarkan dari hasil penelitian dapat diketahui bahwa tingkat kesesuaian kawasan transit Blok $M$, Jakarta berdasarkan dari kriteria minimal yang ada dalam konsep TOD hanya sebesar $\mathbf{8 5 , 2 1 5 \%}$. Artinya pengembangan kawasan Blok $M$, tingkat kesesuaiannya belum sepenuhnya memenuhi kriteria TOD. Secara keseluruhan kawasan Blok M sudah memenuhi ciri densitas yang tinggi, namun diveritas dan desain kawasan yang ramah pejalan kaki masih belum sesuai dengan konsep TOD.
\end{abstract}

Kata Kunci-Blok M Jakarta, Spatial Query, Transit Oriented Development, Urban Design.

\section{PENDAHULUAN}

$\mathrm{S}$ EKTOR transportasi perkotaan akan mengalami berbagai tantangan dalam beberapa tahun kedepan. Hal ini dapat diprediksi dari kenaikan penduduk dunia yang berkisar 2,2 miliar jiwa pada tahun 2010 menjadi 9,2 miliar pada tahun 2050 nantinya dan dua-pertiga penduduk tersebut hidup dan beraktivitas pada kawasan perkotaan. [1].

Kota Jakarta merupakan salah satu kota metropolitan yang memiliki pertumbuhan penduduk yang signifikan setiap tahunnya. Selain pusat pemerintahan, Jakarta juga merupakan pusat kegiatan ekonomi. Hal ini berdampak tingginya pergerakan penduduk yang ada di Jakarta maupun outter Jakarta menuju pusat kegiatan tersebut [2]. Untuk melakukan pergerakan, manusia memiliki dua pilihan yakni bergerak menggunakan moda atau tanpa moda transportasi. Pada dasarnya bergerak menggunakan moda berjarak lebih dari 2 $\mathrm{km}$. Moda transportasi yang digunakan dapat berupa pribadi ataupun publik [3]. Namun masyarakat Jakarta lebih memilih menggunakan kendaraan pribadi. Hal ini terlihat dari penambahan kendaraan bermotor yang terbilang signifikan. Pertumbuhan kendaraan bermotor di Jakarta mencapai 9,93\% degan komposisi sepeda motor $10,54 \%$ dan mobil $8,75 \%$. Jika dibandingkan dengan luas jalan, maka setiap kendaraan bermotor hanya memiliki ruang sebesar 3,02 $\mathrm{m}^{2}$ [4][5] [6].

Permasalahan kemacetan tersebut dapat dikurangi dengan cara mengalihkan orientasi penggunaan kendaraan pribadi ke angkutan massal berbasis transit. Namun juga harus didukung dengan pengembangan urban form yang kompak disekitar titik pergantian moda. Pengembangan kawasan yang berorinteasi pada titik transit agar meningkatkan demand angkutan massal berbasis transit tersebut sering dikenal dengan Transit Oriented Development [7][8]. Berdasarkan pengalaman Kota Arlington, semakin tinggi tingkat kesesuaian kawasan terhadap standart TOD maka semakin tinggi tinggi penggunaan metro ridership (angkutan umum berbasis transit), bahkan penggunaan angkutan umum tersebut naik 263\% dalam waktu 17 tahun ketika konsep TOD diterapkan di koridor Arlington tersebut. Selain itu sebesar $73 \%$ pergerakan dengan berjalan kaki,7,5\% menggunakan metro bus dan hanya $12,9 \%$ yang menggunakan kendaraan pribadi di koridor tersebut [9]. Sehingga dapat disimpulkan manfaat dari rekayasa ruang berdasarkan konsep TOD antara lain dapat mengurangi kemacetan yang ada diperkotaan tersebut, menurunkan ketergantugan penggunaan kendaraan pribadi dengan mengalihkan modanya ke angkutan massal cepat berbasis transit serta memperpendek jarak dan waktu perjalanan masyarakat [10].

Kawasan Blok $M$ yang merupakan salah satu pusat bisnis karena memiliki berbagai kegiatan ekonomi dengan skala Jabodetabek. Selain itu penggunaan lahan di kawasan tersebut sangat bervariasi, berbagai kegiatan juga terdapat pada kawasan ini seperti perkantoran, perdagangan dan jasa, fasilitas umum dan open space serta residential. Kawasan Blok M, Jakarta juga merupakan $h u b$ (titik temu) moda transportasi di Jakarta karena memiliki terminal yang melayani seluruh angkutan kota, baik kopaja, metromini, Bus Transjakarta, APTB ataupun mass rapid transit yang sedang dalam tahap pengerjaan. Walaupun memiliki moda transportasi umum di kawasan tersebut namun penggunaan kendaraan pribadi masih sangat tinggi di kawasan tersebut. Hal ini ditinjau dari presentase penggunaan sepeda motor sebesar $57,96 \%$ dan mobil sebesar $39,81 \%$ dari seluruh presentase kendaraan yang melalui kawasan Blok $\mathrm{M}$ ini. Akibatnya kawasan transit Blok M, Jakarta mengalami 
kemacetan setiap harinya [4].

Padahal pada tahun 2014, berdasarkan Peraturan Daerah Nomor 1 Tahun 2014 pasal 334 mengatakan bahwa Kawasan Blok M merupakan salah satu kawasan yang dikembangkan berdasarkan dari prinsip TOD. Berdasarkan hal tersebut diperlukan penelitian untuk meninjau sejauh mana tingkat kesesuaian pengembangan kawasan transit Blok M, Jakarta terhadap kriteria dari konsep TOD. Sehingga nantinya diharapkan bisa menjadi rekomendasi dalam mendukung urban design guidelines kawasan transit Blok M, Jakarta.

\section{METODE PENELITIAN}

\section{A. Metode Pengumpulan Data}

Pengumpulan data dilakukan dengan cara melakukan survei primer ataupun survei sekunder. Untuk mendapatkan data mengenai karakteristik kawasan transit Blok M dilakukan menggunakan teknik pengumpulan data berupa observasi lapangan serta pengamatan citra satelit. Selain itu juga digunakana survei instansional ke beberapa stakeholders terkait seperti Dinas Perhubungan dan Dinas Cipta Karya,Tata Ruang Pertanahan, Jakarta

\section{B. Variabel Penelitian}

Dalam melakukan analisis kesesuaian kawasan transit digunakan beberapa variabel penelitian sebagai tolak ukur. Penentuan dari variabel penelitian ini didasarkan pada hasil sintesa dari berbagai pustaka ilmiah. Berikut merupakan tabel variabel dari penelitian ini.

Tabel 1.

Indikator, Variabel dan Sub Variabel Penelitian

\begin{tabular}{|c|c|c|}
\hline Indikator & Variabel & Sub Variabel \\
\hline \multirow{4}{*}{ Densitas } & Koefisien Dasar Bangunan & - \\
\hline & Koefisien Lantai Bangunan & - \\
\hline & Kepadatan Kawasan & Kepadatan Bangunan \\
\hline & & Kepadatan Pekerjaan \\
\hline Diversitas & Presentase Land Use & $\begin{array}{l}\text { Presentase Residential } \\
\text { Presentase } \\
\text { Non-Residential }\end{array}$ \\
\hline \multirow{4}{*}{ Desain } & Keberadaan Jalur Pedestrian & - \\
\hline & Dimensi Jalur Pedestrian & - \\
\hline & Kondisi Jalur Pedestrian & $\begin{array}{l}\text { Terdapat Fasilitas Difabel } \\
\text { Pedestrian yang Aman } \\
\text { Pedestrian yang Nyaman }\end{array}$ \\
\hline & Konektifitas Jalur Pedestrian & - \\
\hline
\end{tabular}

\section{C.Metode Analisis}

Dalam melakukan analisis kesesuaian kawasan Blok $\mathrm{M}$ terhadap kriteria TOD dilakukan dengan dua tahapan analisis yakni:

1) Mengidentifikasi Karakteristik Kawasan Transit Blok M, Jakarta Beradasarkan Indikator TOD

Dalam tahapan ini dilakukan dengan menggunakan analisis statistik deskriptif. Proses analisis ini dengan cara mengidentifikasi masing-masing indikator, variabel serta sub variabel penelitian dalam ruang lingkup penelitian yakni $800 \mathrm{~m}$ dari transit point Blok M, Jakarta.

Setelah melakukan radius 800 meter dari titik transit kemudian dilakukan delinasi berdasarkan Perda No 1. Tahun 2014 tentang RDTR dan PZ Jakarta. Kemudian diperoleh 9
Blok sebagai unit analisis penelitian.

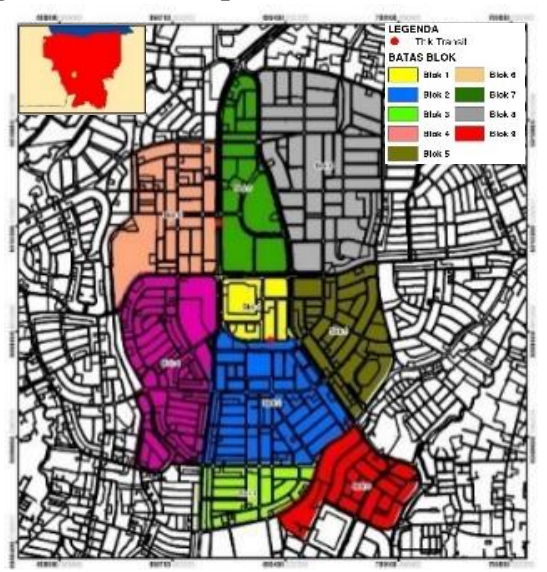

Gambar 1. Ruang Lingkup Wilayah

\section{2) Menganalisis Tingkat Kesesuaian Kawasan Blok M,} Jakarta Terhadap Kriteria TOD

Pada analisis ini dilakukan dengan cara membandingkan karakteristik kawasan terhadap kriteria minimal kawasan berprinsip TOD. Dalam menentukan kriteria tersebut dilakukan dengan cara melakukan sintesa dari berbagai pustaka yang dikemukakan para ahli ataupun dari penelitian sebelumnya.

Tabel 2.

Kriteria TOD

\begin{tabular}{|c|c|c|}
\hline$\overline{\text { Variabel }}$ & Sub Variabel & Kriteria \\
\hline KDB & - & Minimum $70 \%$ \\
\hline KLB & . & Minimum 2.0 \\
\hline & Kepadatan & Minimum terdapat 40 bangunan/ha \\
\hline Kepadatan & Bangunan & \\
\hline Kawasan & $\begin{array}{l}\text { Kepadatan } \\
\text { Pekerjaan }\end{array}$ & $\begin{array}{l}\text { Minimum terdapat } 400 \\
\text { jobs/ha }\end{array}$ \\
\hline Presentase & $\begin{array}{l}\text { Presentase } \\
\text { Residential }\end{array}$ & $\begin{array}{l}\text { Presentase penggunaan lahan } \\
\text { sebesar: }\end{array}$ \\
\hline Land Use & $\begin{array}{l}\text { Presentase } \\
\text { Non-Residential }\end{array}$ & $\begin{array}{ll}\text { - } & \text { Residential 20\% } \\
\text { - } & \text { Non-Residential } 80 \%\end{array}$ \\
\hline $\begin{array}{l}\text { Keberadaan } \\
\text { Jalur }\end{array}$ & - & $\begin{array}{l}\text { Keberadaan jalur pedestrian pada } \\
\text { blok sebesar } 100 \% \text { dari segmen }\end{array}$ \\
\hline Pedestrian & & jalan \\
\hline Dimensi & & Lebar jalur pedestrian jalan arteri \\
\hline $\begin{array}{c}\text { Jalur } \\
\text { Pedestrian }\end{array}$ & - & $\begin{array}{l}1,8 \mathrm{~m} \text {, jalan kolektor dan jalan lokal } \\
1,2 \mathrm{~m}\end{array}$ \\
\hline & $\begin{array}{l}\text { Terdapat Fasilitas } \\
\text { Difabel }\end{array}$ & Terdapat bollard dan paving tactile \\
\hline $\begin{array}{l}\text { Kondisi Jalur } \\
\text { Pedestrian }\end{array}$ & $\begin{array}{l}\text { Pedestrian yang } \\
\text { Aman }\end{array}$ & $\begin{array}{l}\text { Terdapat (PJU) Penerangan Jalan } \\
\text { Umum dan Fasilitas penyebrangan } \\
\text { (JPO atau Zebra Cross) }\end{array}$ \\
\hline & $\begin{array}{l}\text { Pedestrian yang } \\
\text { Nyaman }\end{array}$ & $\begin{array}{l}\text { Terdapat pohon peneduh serta } \\
\text { kanopi }\end{array}$ \\
\hline $\begin{array}{c}\text { Konektifitas } \\
\text { Jalur } \\
\text { Pedestrian }\end{array}$ & - & $\begin{array}{l}\text { Waktu tempuh perjalanan dari titik } \\
\text { transit yaitu } 10 \text { menit }\end{array}$ \\
\hline
\end{tabular}

Setelah membandingkan karakteristik kawasan dengan kriteria TOD kemudian dihitung tingkat kesesuaian kawasan menggunakan nilai rata-rata indikator (densitas, diversitas dan desain kawasan). Selanjutnya, hasil perhitungan tersebut diratarata serta dipetakan menggunakan spatial query pada ArcGis. 


\section{HASIL DAN DISKUSI}

\section{A. Identifikasi Karakteristik Kawasan Transit Blok M, Jakarta Berdasarkan Indikator TOD}

Ruang lingkup penelitian yang merupakan radius $800 \mathrm{~m}$ dari transit point memiliki luas lahan sebesar 370,005 ha. Seluruh blok pada wilayah studi termasuk kedalam wilayah administrasi Kecamatan Kebayoran Baru dan terdiri dari beberapa kelurahan yaitu Kelurahan Selong, Melawai, Gunung, Kramat Pela, dan Pulo.

Berdasarkan dari hasil identifikasi, untuk indikator densitas yang memiliki variabel koefisien dasar bangunan rata-rata, koefisien lantai bangunan rata-rata serta kepadatan kawasan termasuk ke dalam kategori densitas yang sudah tinggi. Hal ini dapat disimpulkan bahwa pada kondisi eksisting di kawasan Blok M nilai KDB rata-rata setiap bloknya yaitu $63,7 \%$. Sama halnya dengan dengan KDB, KLB rata-rata setiap bloknya di kawasan transit Blok $\mathrm{M}$ juga tergolong tinggi karena memiliki nilai 1,83. Jika ditinjau dari variabel kepadatan kawasan, untuk sub variabel kepadatan bangunan masih tegolong cukup tinggi. Hal ini dikarenakan kepadatan bangunan di kawasan tersebut sebesar 25 bangunan/ha. Sedangkan untuk kepadatan pekerjaan, di kawasan transit ini sebesar 912 pekerjaan/ha atau dengan kata lain ketersediaan pekerjaan pada kawasan Blok M ini sangat tinggi. Berdasarkan dari pustaka semakin tinggi rasio KDB rata-rata, KLB rata-rata serta kepadatan bangunan dan kepadatan pekerjaan di suatu kawasan maka akan menyebabkan semakin tinggi bangkitan yang dihasilkan ataupun tarikan pergerakan masyarakat menuju kawasan tersebut.

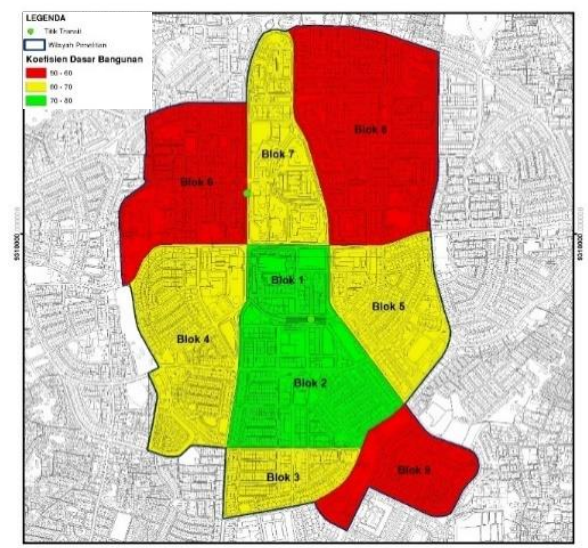

Gambar 3. Peta Klasifikasi KDB

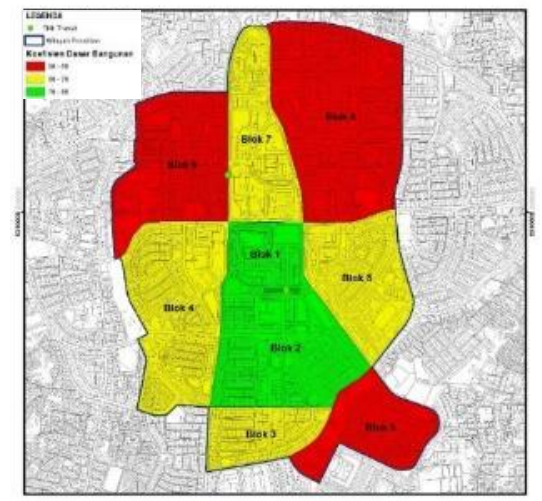

Gambar 4. Peta Klasifikasi KLB

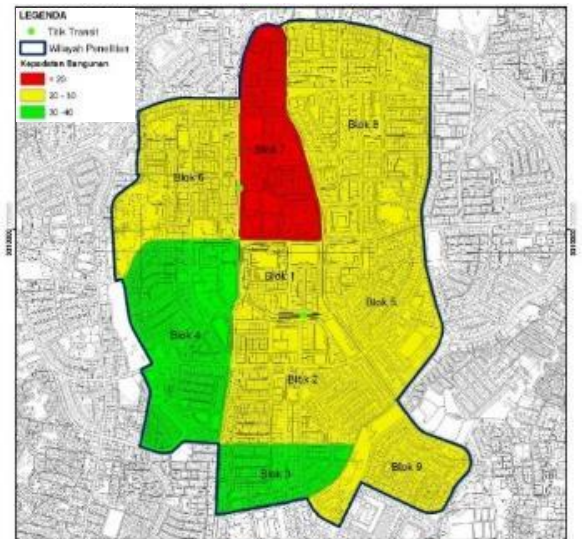

Gambar 5. Peta Klasifikasi Kepadatan Bangunan

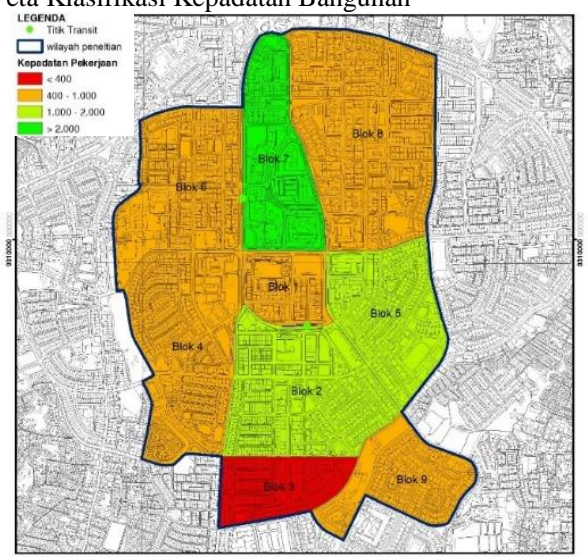

Gambar 6. Peta Klasifikasi Kepadatan Pekerjaan

Jika dilihat dari indikator diversitas, penggunaan lahan di kawasan transit Blok $\mathrm{M}$ dapat diklasifikasin menjadi 4 bagian yaitu residential, fasilitas umum dan open space, perkantoran serta perdagangan dan jasa. Berdasarkan hasil identifikasi didapatkan presentase penggunaan lahan jenis residential sebesar $54,7 \%$. Sedangkan fasilitas umum dan open space sebesar $16,1 \%$, perkantoran sebesar $11,2 \%$, perdagangan dan jasa $18 \%$. Sehingga dapat dikatakan presentase penggunaan lahan non-residential 45,3\%.

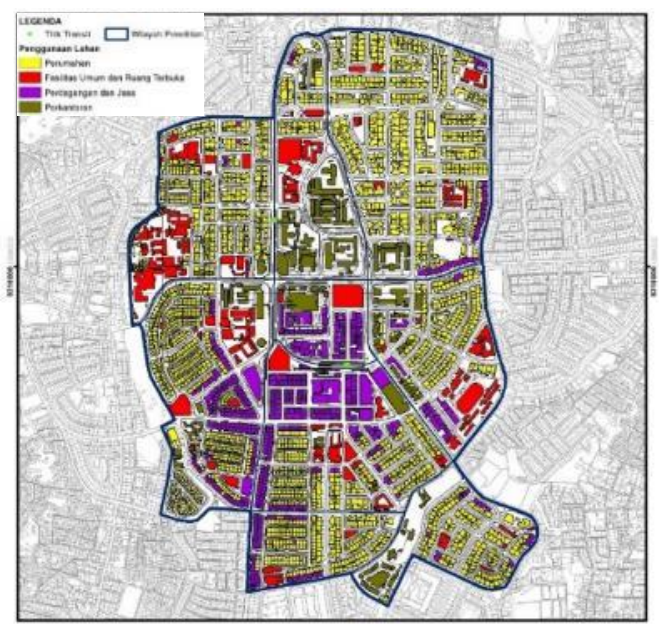

Gambar 7. Penggunaan Lahan 
Pada indikator desain kawasan, keberadaan jalur pedestrian yang terdapat pada kawasan transit Blok $\mathrm{M}$ hanya sebesar $68,8 \%$ dari total panjang jalan yang ada pada setiap bloknya.

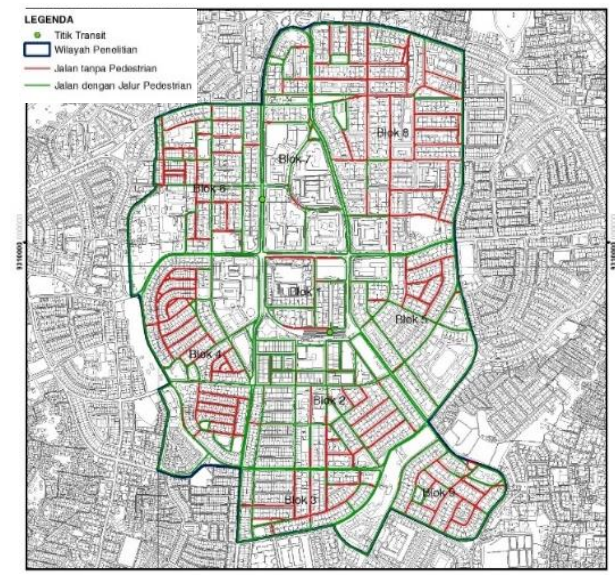

Gambar 8. Keberadaan Pedestrian

Selain itu lebar rata-rata dimensi jalur pedestrian di kawasan Blok M dengan fungsi jalan arteri sebesar 2,275 m. Sedangkan untuk fungsi jalan kolektor sebesar 2,2 m dan lokal sebesar 1,3 m. Pada kawasan transit Blok M belum ramah pejalan kaki jika ditinjau dari kondisi jalur pedestrian karena belum terdapat fasilitas penujang difabel seperti bollard dan paving tactille, fasilitas kenyamanan pejalan kaki seperti pohon peneduh dan kanopy serta fasilitas pemberi rasa aman bagi pengguna pedestrian seperti jembatan penyebarangan orang atau zebra cross dan penerangan jalan umum. Untuk konektivitas jalur pedestrian, rata-rata waktu tempuh dari transit point menuju berbagai blok di kawasan transit tersebut adalah 10 menit 26 detik.

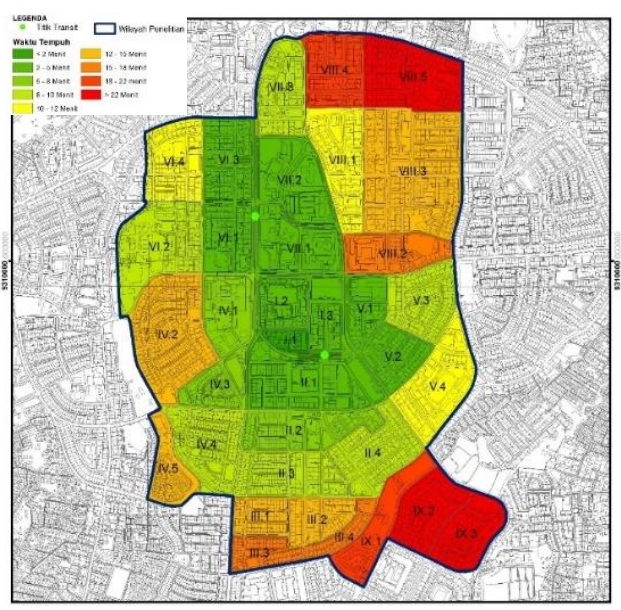

Gambar 9. Konektivitas Pedestrian

\section{B. Analisis Tingkat Kesesuaian Kawasan Blok M, Jakarta Terhadap Kriteria TOD}

Dalam menganalisis tingkat kesesuaian kawasan transit dilakukan dengan cara menghitung karakteristik masingmasing variabel ataupun sub variabel dibagi dengan kriteria yang telah ditentukan sebelumnya. Hal ini bertujuan untuk mengetahui sejauh mana kesesuaian kawasan Blok M dengan kriteria minimal TOD. Setelah mendapatkan tingkat kesesuaian masing-masing variabel ataupun sub variabel terhadap kriteria minimal TOD, kemudian hasil tersebut dirata-ratakan berdasarkan indikator (densitas, diversitas dan desain). Berikut merupakan tabel perhitungan kesesuaian karakteristik kawasan terhadap kriteria TOD.

Tabel 3.

Nilai Kesesuaian Kawasan Blok M, Jakarta

\begin{tabular}{|c|c|c|c|c|}
\hline Variabel & $\begin{array}{c}\text { Sub } \\
\text { variabel }\end{array}$ & Eksisting & Kriteria & $\begin{array}{c}\text { Nilai } \\
\text { Kesesuaian }\end{array}$ \\
\hline \multicolumn{5}{|c|}{ Densitas } \\
\hline KDB & - & $63,7 \%$ & $70 \%$ & $91 \%$ \\
\hline KLB & - & 1,83 & 2,0 & $91,3 \%$ \\
\hline $\begin{array}{c}\text { Kepadatan } \\
\text { Kawasan }\end{array}$ & $\begin{array}{l}\text { Kepadatan } \\
\text { Bangunan }\end{array}$ & 25 & 40 & $62,5 \%$ \\
\hline & $\begin{array}{l}\text { Kepadatan } \\
\text { Pekerjaan }\end{array}$ & 912 & 400 & $228,1 \%$ \\
\hline $\begin{array}{c}\text { Nilai } \\
\text { Rata-Rata } \\
\text { Densitas }\end{array}$ & \multicolumn{4}{|c|}{$109,1 \%$} \\
\hline \multicolumn{5}{|c|}{ Diversitas } \\
\hline $\begin{array}{c}\text { Presentase } \\
\text { Penggunaan } \\
\text { Lahan } \\
\text { Nilai }\end{array}$ & - & $\begin{array}{l}\text { Res: } 54,7 \% \\
\text { Non: } 45,3 \%\end{array}$ & $\begin{array}{l}\text { Res: } 20 \% \\
\text { Non: } \\
80 \%\end{array}$ & $56,62 \%$ \\
\hline $\begin{array}{l}\text { Rata-Rata } \\
\text { Diversitas }\end{array}$ & \multicolumn{4}{|c|}{$56,62 \%$} \\
\hline \multicolumn{5}{|c|}{ Desain } \\
\hline $\begin{array}{l}\text { Keberadaan } \\
\text { Jalur } \\
\text { Pedestrian }\end{array}$ & \multicolumn{4}{|c|}{$\begin{array}{l}\text { Panjang pedestrian terhadap segmen } \\
\text { jalan hanya sebesar } 68,8 \%\end{array}$} \\
\hline $\begin{array}{l}\text { Dimensi Jalur } \\
\text { Pedestrian }\end{array}$ & - & \multicolumn{3}{|c|}{ Nilai Kesesuaiannya $128,5 \%$} \\
\hline & $\begin{array}{l}\text { Terdapat } \\
\text { Fasilitas }\end{array}$ & & & \\
\hline $\begin{array}{l}\text { Kondisi Jalur } \\
\text { Pedestrian }\end{array}$ & $\begin{array}{c}\text { Difabel } \\
\text { Pedestrian } \\
\text { yang Aman } \\
\text { Pedestrian } \\
\text { yang } \\
\text { Nyaman }\end{array}$ & \multicolumn{3}{|c|}{$\begin{array}{l}\text { Nilai Kesesuaian Kondisi Jalur } \\
\text { Pedestrian sebesar } 66,6 \% \text { dari kriteria } \\
\text { minimal TOD }\end{array}$} \\
\hline $\begin{array}{c}\text { Konektivitas } \\
\text { Jalur } \\
\text { Pedestrian } \\
\text { Nilai }\end{array}$ & - & \multicolumn{3}{|c|}{$\begin{array}{l}\text { Nilai Kesesuaian Konektivitas dari titik } \\
\text { transit ke pusat aktivitas sebesar } 95,8 \%\end{array}$} \\
\hline Rata-Rata & \multicolumn{4}{|c|}{$89,925 \%$} \\
\hline & \multicolumn{4}{|c|}{ Nilai Rata $($ Densitas $)+($ Diversitas $)+($ Desain $)$} \\
\hline $\begin{array}{c}\text { Nilai } \\
\text { Rata-Rata }\end{array}$ & \multicolumn{4}{|c|}{3} \\
\hline $\begin{array}{l}\text { Kesesuaian } \\
\text { Kawasan }\end{array}$ & \multicolumn{4}{|c|}{$\frac{109,1 \%+56,62 \%+89,925 \%}{3}=85,215 \%$} \\
\hline
\end{tabular}

Jika dilihat dari tabel diatas dapat diketahui bahwa nilai kesesuaian terkait KDB, KLB dan kepadatan bangunan masih belum memenuhi standar minimal TOD, akan tetapi kepadatan pekerjaan yang tersedia di kawasan Blok M sangat tinggi. Hal ini dikarenakan kawasan Blok $\mathrm{M}$ merupakan kawasan perdagangan dan jasa serta memiliki banyak perkantoran. Sehingga nilai kesesuaian indikator densitas sebesar 109,1\%. Sedangkan untuk indikator diversitas, penggunaan lahan masih didominasi oleh residential dengan perbandingan residential $54,7 \%: 45,3 \%$ non residential, seharusnya kawasan TOD memiliki perbandingan sebesar $80 \%$ untuk komersial dan $20 \%$ untuk residential. Dari perhitungan didapatkan nilai kesesuaian untuk indikator diversitas sebesar $56,62 \%$. Indikator desain memiliki nilai kesesuaian sebesar $89,925 \%$. Hal ini dikarenakan keberadaan jalur pedestrian pada setiap bloknya hanya sebesar 
68,8\% dari total segmen jalan. Akan tetapi, dimensi jalur pedestrian di kawasan Blok M sudah baik. Untuk kondisi jalur pedestrian yang ditinjau berdasarkan ketersediaan sarana penunjang pedestrian memiliki nilai kesesuaian $66,6 \%$. Hal ini dikarenakan sarana penunjang tersebut belum semuanya tersedia di setiap bloknya. Rata-rata waktu tempuh perjalanan ke setiap blok di kawasan Blok M adalah 10 menit 26 detik. Padahal kawasan berbasis TOD seharusnya memiliki konektivitas sebesar 10 menit. Berdasarkan dari nilai kesesuaian masing-masing indikator, kemudian didapatkan nilai kesesuaian secara kawasan yakni 85,215\%.

\section{KESIMPULAN}

Berdasarkan dari hasil analisis dapat disimpulkan bahwa kawasan Blok $\mathrm{M}$ hanya memiliki tingkat kesesuaian sebesar $85,215 \%$. Artinya, pengembangan kawasan Blok M belum memenuhi standar minimal dari konsep TOD. Dari ketiga indikator TOD, hanya densitas yang melampaui kriteria minimal yang telah ditentukan. Sedangkan untuk indikator diversitas serta desain kawasan, nilai kesesuaiannya masih dibawah $100 \%$ atau masih belum sepenuhnya sesuai dengan standar minimal TOD. Tingkat kesesuaian indikator densitas sebesar 109,1\%. Hal ini dikarenakan KDB, KLB rata-rata serta kepadatan kawasan yang ditinjau dari kepadatan bangunan dan pekerjaan di kawasan Blok M sudah padat. Indikator diversitas hanya memiliki nilai kesesuaian sebesar $56,62 \%$. Selain itu tingkat kesesuaian desain kawasan hanya 89,925\%. Berdasarkan hal tersebut dapat diketahui bahwa konsep TOD yang sudah direncanakan dan dikembangkan sejak tahun 2014, pada kenyataannya kawasan transit Blok $\mathrm{M}$ masih belum sepenuhnya memenuhi kriteria minimal TOD.

\section{DAFTAR PUSTAKA}

[1] P. Gadonneix, “Global Transport Scenarios 2050,” London, 2011.

[2] B.P.S, Jakarta Dalam Angka 2016. DKI Jakarta: Badan Pusat Statistik, 2016.

[3] O. Z. Tamin, Perencanaan \& Pemodelan Transportasi. Bandung: ITBpress, 2000.

[4] B.P.S, Statistik Transportasi DKI Jakarta 2015-2016. DKI Jakarta: Badan Pusat Statistik, 2016.

[5] J. Kusumaningrum, "Analisa Perbandingan Kinerja Jalan Jenderal Sudirman Sebelum dan Sesudah Perpanjangan Waktu Three In One dan Penerapan Busway,” Din. Tek. Sipil, vol. 11, no. 1, pp. 70-80, 2009.

[6] H. Sukarto, "Pemilihan Model Transportasi di DKI Jakarta dengan Analisis Kebijakan 'Proses Hirarki Analitik," J. Tek. Sipil, vol. 3, no. 1, pp. 25-36, 2006.

[7] R. Cervero, "Linking urban transport and land use in developing countries," J. Transp. Land Use, vol. 6, no. 1, pp. 7-24, 2013.

[8] R. Cervero, "Public Transport and Sustainable Urbanism: Global Lessons," Sci. Counc. Japan, pp. 1-10, 2006.

[9] P. River, "Large Community Case Study : Rosslyn-Ballston Corridor , Arlington, Virginia,” Long Isl. Index, pp. 1-16, 2011.

[10] C. Hutton, Florida TOD Guidebook, no. December. Florida: Treasure Coast Regional Planning Council, 2012. 